\title{
Leadership-in-Teams, Ready, Willing and Able: Perspectives of International Accounting Students
}

\begin{tabular}{|r|l|}
\hline Journal: & Meditari Accountancy Research \\
\hline Manuscript ID & MEDAR-05-2019-0499.R3 \\
\hline Manuscript Type: & Research Paper \\
\hline Keywords: & Accounting cirriculum, Teamwork, Leadership, RWA Framework \\
\hline \multicolumn{2}{|l}{} \\
\end{tabular}


Leadership-in-Teams, Ready, Willing and Able: Perspectives of International Accounting Students

\author{
Abstract \\ Purpose \\ This study explores the reasons why international accounting students in higher education in Australia \\ do not accept leadership roles in academic teams, considering the importance employers attach to \\ leadership and teamwork graduate attributes. \\ Design/methodology/approach
}

Adopting the Keating et al. (2014) ready, willing and able (RWA) leadership framework, this qualitative study uses a narrative textual approach to analyse the data from responses to open-ended questions recorded in interviews with a sample of Master of Professional Accounting (MPA) students ( $N=12$ ) undertaking leadership-in-team roles in a management and cost Accounting unit $(\mathrm{N}=110)$ within an Australian higher education accounting program.

Findings

The findings of the study suggest that a lack of past work experience disadvantages accounting students in being 'ready' to adopt leadership roles in teams. Self-interested behaviour results in students not being 'willing' to adopt leadership roles. Students perceive business simulation and work-integrated learning activities to hold the potential to improve their 'ability' to lead.

Practical implications

The study offers a conceptual schema for student leadership development, suggesting that accounting curricula in higher education should include the assessment of scaffolded leadership development activities. Mentorship roles in academic teams should be explored. 


\section{Originality/value}

To our knowledge, this is the first application of the RWA framework to explore accounting students' predisposition to accepting leadership roles in teams. Informed by the student narrative, we offer a future focused RWA schema as a practical guide for educators to embed leadership development in the accounting curriculum.

Keywords: Accounting curriculum, Teamwork, Leadership, RWA framework Type: Research Paper

\section{Introduction}

Employers seek graduates who are astute, emotionally intelligent and who display a range of professional skills (Barac, 2009; Pham and Thompson, 2019; Nelson et al., 2016). This has resulted in a growing demand for accounting students to have a rounded education that enables them to be effective leaders and team members in a myriad of business situations across a variety of political landscapes and cultural settings (O'Connell et al., 2015; Stainbank, 2009). Professional accounting bodies and commentators have called for a change in the way accountants are educated, as little consideration is currently given in the accounting curriculum to developing professional skills, such as leadership competency and communication, alongside technical skills (O'Connell et al., 2015; Samkin and Stainbank, 2016). By adopting educational platforms designed to blend technical skills with professional skills, accounting students will benefit from exposure to various types of leadership in practical and simulated business settings (Ellis et al., 2015; Kaciuba, 2012).

Accounting students get involved in activities and behave assuredly when they judge themselves capable of handling situations (Beatson et al., 2019). However, it has been suggested that accounting students have lower levels of emotional intelligence skills, including self-efficacy in leadership, as 
compared with non-accounting students (Daff et al., 2012). How to integrate training in techniques to improve emotional intelligence and encourage accounting students to take these techniques on board remains a challenge (Kennedy and Dull, 2008). Developing leadership skills as a learning outcome in the accounting curriculum can only be achieved if accounting students accept leadership roles in teamwork projects (Huff, 2014). Considering the importance of leadership capabilities to employers, this study broadly wishes to explore why some accounting students avoid taking on leadership roles in academic teams and how can this be remedied.

This study responds to the call by Daff et al. (2012) for accounting educators to consider more rigorous adoption of emotional intelligence competencies, including more initiatives designed to develop accounting students' leadership abilities to inspire and develop others. Accordingly, this study applies the Keating et al. (2014) ready, willing and able (RWA) student leadership development framework in a management and cost accounting setting at a regional Australian university by interviewing a sample of students with open-ended questions based on the constructs of the Keating et al. (2014) framework. From this application, we use the student narrative to develop a conceptual schema to develop accounting students' leadership skills.

The findings of the study suggest that a lack of past work experience disadvantages accounting students in being 'ready' to adopt leadership roles in teams. Pursuit of high-quality grades and time constraints were reasons respondents offered for accounting students' not being 'willing' to adopt leadership roles. Interviewees reported that a lack of accounting students' 'ability' in adopting leadership roles often derives from a lack of opportunity to practise leadership skills in schooling and undergraduate degrees.

The background to the study follows in the next section. In section 3, we consider relevant literature and our exploratory research question. In sections 4 and 5, we explain our theoretical approach and method. We report our findings in section 6 . We offer our conclusions in section 7 and provide practical 
suggestions to improve pedagogical outcomes and call for future research. Limitations to our study are acknowledged where appropriate.

\section{Background}

Education as an export commodity is increasingly important for developed countries. For example, the Australian economy benefits from annual revenue in excess of $A \$ 30$ billion (Robinson, 2018), with a large component of international business students enrolling in accounting courses (O'Connell et al., 2015). Though this revenue stream is under threat due to the COVID-19 pandemic, Australian business schools' remain committed to maintain and increase revenue from international business student enrolment has led to increased prominence given to accreditation and reaccreditation with bodies, such as the Association to Advance Collegiate Schools of Business (AACSB). The AACSB standards form the basis of assurance to stakeholders that graduate capabilities are sufficiently developed ( $O^{\prime}$ Connell et al., 2016). Accreditation thus serves as a powerful marketing tool to increase revenue from the enrolment of international students.

Nyland et al. (2013) are critical of this approach and argue that Australian universities should shift their focus from improving profits through aggressive recruiting of international students to developing students' graduate attributes, particularly communication, interpersonal, language and team-related skills. From an employer's viewpoint and an accounting education standards perspective, accounting educators have failed to provide appropriately qualified graduates (Birrell and Betts, 2018; Daff et al., 2012; Dyball et al., 2007), perhaps due to a perception among academics that development of graduate attributes is not their responsibility (Evans et al., 2009) or as a result of the misguided notion that universities should be 'prospectors...for gold'1 (Nyland et al., 2013).

\footnotetext{
${ }^{1}$ Prospectors for gold are preoccupied with financial riches associated with a gold strike.
} 
From a regulatory perspective, the Australian Tertiary Education Quality and Standards Agency demands the development of a broad range of graduate professional skills. In providing evidence of meeting the regulatory standards, the Australian accounting learning standards (AALS) and international education standards (IES) provide a professional, external benchmark to business schools to guide the design of the accounting curriculum and Assurance of Learning activities by setting standards for threshold learning outcomes and assessment (Watty et al., 2014).

To comply with the relevant AALS (similar to the IES teamwork prescript), the following leadership-inteams learning objective was included during 2017 in a cost and management accounting unit in a Master of Professional Accounting (MPA) course: Develop a cohesive team structure and reflect on roles of self and peers. As a learning outcome, this satisfies the AALS leadership-in-teams standard pertaining to a master's level: within the 'Teamwork standard' and to 'Contribute accounting expertise in a leadership capacity to a diverse team collaboratively providing possible solutions to an emerging and/or advanced business problem in a complex context' (ABDC, 2017).

The MPA course in Australian universities is typically an intensive two-year program aimed at creating an opportunity for graduates to acquire the necessary technical skills to practise as accountants. The MPA course offers a popular pathway to professional accounting affiliation. Due to the intensive nature of the degree, it is a challenge for accounting educators in MPA programs to find ways to embed and scaffold professional skills development in curricula that are historically dominated by technical skills development.

In attempting to develop professional skills together with technical skills in the MPA course in question, the intended leadership-in-teams learning outcome was incorporated with learning objectives designed to develop technical skills in a management and cost accounting unit. Technical skills taught and subsequently assessed in a teamwork project included break-even analysis and product-mix decision- 
making based on contribution margin analysis and Excel skills. Although the leadership-in-teams learning objective carried an assessment weighting of $20 \%$, the main aim was to confirm the learning outcome as having been met rather than measuring a level of proficiency. A survey to elicit students' opinion on the leadership-in-teams learning outcome found that a surprisingly large percentage (>30\%) of students reported they did not hold a position of leadership in their group, even though each was expected to take responsibility for different aspects of the group project. To develop an understanding of why this may be the case, a literature review of the leadership-in-teams phenomenon in an accounting education context was undertaken.

\subsection{Literature review - professional skills development}

Accounting education has traditionally focused on the development of technical skills and has given little attention to professional skills (Boyce et al., 2012). From their reflective case study on how a group of academics have sought to enact accounting education reform, Boyce et al. (2012) argue that conventional accounting education does not produce well-rounded and versatile graduates, as it mostly ignores social-political and cultural aspects of accounting. They posit that teaching cultural and Australian social constructs (including leadership) blended with technical skills will prepare higherquality work-ready graduates and call for change in the content and practice of classroom activity to achieve this end.

Bryant and Albring (2006) compiled 12 guidelines to assist accounting educators in guiding effective teambuilding. From their review of sociology, industrial psychology and organizational behaviour literature, they argue that academic teams should appoint a team coordinator (Guideline 5) rather than following a shared leadership model commonly used in academic settings. The team coordinator (leader) is responsible for keeping the team on track and focused during the project. This does not 
facilitate leadership development for all students in line with leadership development learning outcomes.

Daff et al. (2012) juxtapose CPA and CA generic skills guidelines for constructs of social awareness and relationship management with an emotional intelligence framework derived from prior literature. They argue that emotional intelligence competencies, such as inspirational leadership, developing others and building bonds, are not addressed by the generic skills guidelines. The authors argue convincingly that accounting educators should consider more rigorous adoption of emotional intelligence competencies in curricula the curriculum, considering the importance employers attach to these professional skills. They conclude that the growing demand for students to be effective leaders necessitates that accounting faculty identify gaps in skills development by using a combination of generic skills guidelines and emotional intelligence frameworks. In this paper, we respond to the call by researchers for accounting educators to develop broader professional skills in our students by exploring means of embedding student leadership development in the accounting curriculum.

\subsection{Literature review - leadership in teams}

Becoming educated and trained in mentoring team leaders is no easy task and requires familiarity with disciplines and processes in which accounting educators are often not well versed (Bonanno et al., 1998). Skill-specific training by accounting educators holds great potential, not just in developing graduate attributes (Reitsma et al., 2016), but it also creates an opportunity for students to develop their self-efficacy (Beatson et al., 2019).

High technical and social ability, in combination with the capacity to lead peers, enhances the effectiveness of teamwork, making it a feasible and effective learning practice in accounting subjects with large international enrolments (Bacon et al., 1999; Dyball et al., 2007; Strand et al., 2004). However, universities need to ensure that international students are on an equal footing with domestic 
students to participate in, and gain from, leadership-in-teamwork (Cruickshank et al., 2012). For example, Cruickshank et al. (2012) assisted international students by working through subject readings, before and after each session, so that they had time out of class to acquire the terminology and concepts.

From her study of 166 undergraduate cost-accounting students, Huff (2014) argues that students can develop their leadership skills through each student taking a leadership role in a portion of a group project. By allocating individual team members specific leadership roles in a group project, students can see how different leadership styles work (or do not work) in culturally diverse situations (Kennedy and Dull, 2008; Stanley and Marsden, 2012). When disagreement in a culturally diverse setting arises, mentorship on how to seek support or consensus will give the students opportunities to develop more advanced leadership skills. It is not enough to argue for working in groups, as group work by itself does not necessarily ensure social or cognitive benefits for international students working in self-selected teams. Unless adequately guided, group work could confirm, or even construct, the power and dominance of some groups of students. This may lead to marginalisation and lack of participation of students from different classes, gender and ethnicity (Cruickshank et al., 2012; Chen and Warren, 2012), and thus requires exposure to higher-order relational and connective leadership styles. This study expands on the Huff (2014) approach by exposing students to different leadership styles by allocating leadership roles in a group that requires different approaches. In response to the Huff (2014) call for more contemporary creative-thinking assignments in graduate-level managerial accounting classes, this study aims to explore the leadership development learning outcomes incorporated in such an assignment.

Lipman-Blumen (1992) report a strong correlation between intercultural competencies and connective leadership. Connective leaders are inclusive and seek connection across cultures and contexts. Studying the intercultural competence and leadership constructs together provided insight into the ability to lead 
across cultures (Cartwright, 2012). Developing effective leaders among tertiary students across ethnic backgrounds is a non-uniform, complex process. By modifying the learning environment, moving away from the traditional lecture-tutorial models to a workshop approach (linked to technology enhancement), the smaller group activity will allow for greater interaction between students from different cultures.

Leadership capacity is linked to important academic, career and life benefits, such as the ability to cope and overcome stereotypes and the adaptation to and persistence in the face of challenging situations (Nguyen, 2016). Nguyen's (2016) quantitative study focuses on international students' confidence in their leadership abilities while studying in a foreign country compared with their domestic student peers. Findings suggest that college campuses and higher education professionals need to do a better job at engaging their international students in leadership opportunities while being culturally relevant. The study found that campus support services and programming are not meeting the needs of international students equally, since they are domestic student-dominated and domestic studentcentric and are often not sensitive to the cultural norms of other countries.

\subsection{Literature review - the RWA framework and its application in an international context}

The Keating et al. (2014) framework holds that three interrelated constructs of capacity should be present in leaders. Firstly, leaders should be ready to act as leaders by showing the necessary selfefficacy or confidence in their own ability to lead. Secondly, leaders should be willing to lead by exhibiting the necessary motivation to lead. Thirdly, leaders should be able to lead by showing the necessary leadership skills.

According to the Keating et al. (2014) RWA developmental model, while some skill (ability) is a prerequisite for display of leadership, students must also simultaneously be prepared to practice the skill (readiness) and to expend energy to repeat the display of leadership (willingness). From their study of 
165 students in a unit - Leadership Studies - at a research-extensive mid-western US university, they concluded that for leadership development to be effective, all three interrelated construct models must be present.

Using the RWA framework in their study of 188 international students in a large US research extensive leadership education centre, Collier and Rosch (2016) conclude that international students are often not ready, willing or able to lead academic teams and argue that leadership education could be used as a portal for institutions to help international students become more embedded in campus communities. Collier and Rosch (2016) suggest that international students lag domestic students in motivation to lead (willingness) stemming from an image of themselves as a leader among peers, as well as from feeling a sense of responsibility to lead only from groups to which they feel they belong (readiness).

Rosch (2015) incorporates the RWA leadership development framework in his study of classroom-based team experiences of 285 engineering students in the US. Rosch (2015) finds that the development of leadership (ability) largely did not occur within the environment of a rigorous, goal-orientated collaborative team experience. Simply placing students in teams did not enhance leadership development. Rosch concludes that in line with the RWA framework, structured forethought and postexperience reflection is required to enhance leadership development.

Through application of the RWA framework, Rosch and Nelson (2018) find strong leadership developmental relationships between past high school and current involvement in student organisations. Their study of 757 registered student organisations associated with a large US university found high school involvement in formal organisations to be critically important in developing the (willingness) dimension of leadership capacity. They conclude that mentoring of student leaders within the ambit of formal student organisations is a powerful avenue to develop leadership skills. 


\section{Conceptual framework}

The Keating et al. (2014) model for development of student leadership capacity serves as the primary frame for this study. An individual's self-efficacy, or appraisal of ability to lead, will precede any conscious decision to participate in leadership. It may well be that individuals have conviction in their own effectiveness but may decide not to engage for different reasons. This study therefore explores not only confidence in or self-efficacy with leadership, but also more broadly within the RWA framework other reasons why accounting students may not be ready, willing, or able to engage in leadership activities.

By considering the three interrelated constructs independently, the RWA framework thus provides a useful schema to develop a deeper understanding across a possibly broad range of reasons why accounting students may not have the capacity to lead. By focusing on problematic areas whilst exploring the research question in detail, more effective leadership development models can be adopted for use in accounting education. 
As reflected earlier in the paper, MPA programs in Australian universities attract large numbers of international students. The successful application of the RWA framework in the Collier and Rosch (2016), Rosch (2015) and Rosch and Nelson (2018) studies thus provide reassurance of the suitability of the RWA framework to develop research questions on leadership-in-teams in the accounting education environment focusing on international students.

\section{Method}

The study follows a qualitative approach to develop an understanding of social life and how people construct meaning in natural settings. As cultural objects, the views of respondents are situated in its social context to convey meaning. Accordingly, the study aims to develop an understanding of the social meaning of the narrative of a community of accounting students (Lapan et al., 2011) by emphasising what the respondents think and how they interact based on the words they use (Neuman, 2013, p. 180).

The study interprets how participants understand their leadership-in-teams situation by analysing research interviews as the primary source of data collection (Clegg and Stevenson, 2013). Rather than using the transcribed interviews as a neutral container of content by statistically analysing data, the documents are interpreted in the larger context of its creation, distribution, and reception. To derive social meaning, the transcriptions are probed and discovered in a manner similar to reading a book, in contrast with a content analysis approach which follows a quantifiable objective approach (Neuman, 2013, p. 180).

\subsection{Research context and sample selection}

The leadership-in-teams learning outcome is incorporated in a case-based, team-learning project in a cost and management accounting unit offered at a regional Australian university in the School of Business and Economics. The project is based on an instructional case (Samuels and Sawers, 2016). It requires the application of cost and management accounting techniques to offer management advice on 
efficient utilisation of constrained resources in a simulated craft beer micro-brewery in Australia. From a technical perspective, the project requires the team to analyse product data bearing in mind the contribution margin per constrained resource by using the solver or similar elementary programming function in MS Excel. The team is required to communicate their advice to a client through the medium of a written report compiled in MS Word. The advice centres on which of three complementary products should be promoted more aggressively and whether a new product should be developed. The teams are required to address social and environmental responsibility (SER) costs with reference to water usage and responsible disposal of waste generated during manufacturing.

The leadership-in-teams learning outcome entails students being exposed to a range of schools of thought on leadership with the opportunity to practise and reflect on each. Exposure to four schools of thoughts on leadership (Cartwright, 2012) were considered appropriate in the context of the project. Transactional-transformational leadership accentuates the desirable attributes of being a good leader (Bass, 1990). This traditional notion of leadership, nested in the command-and-control styles of leadership, focuses on aspects such as leading by example, punctuality and timely reporting. In contrast, the relational school of leadership (Graen and Uhl-Bien, 1995) emphasise a sense of in-group belonging based on cooperation rather than competition or individualism. Leadership is accordingly evaluated based on the quality of relationships. The information-processing school of leadership (Lord et al., 1984) focuses on how decision-making is constrained through followers' perceptions of leadership. The quality of leadership is measured on the level of acceptance of directives by followers. The connective leadership model (Lipman-Blumen, 1992) seeks to build a better world through leadership that recognises interdependence and diversity. The quality of leadership is measured on how successful diversity can be managed to achieve synergies.

The leadership-in-teams learning outcome was aligned to simulated business meetings. The instructors in the cost and management accounting unit facilitate the self-adoption of individual roles and 
responsibilities by allowing in-class time for deliberation and decision-making to establish individual accountability. To develop leadership attributes in line with the stated leadership-in-teams learning outcomes, each member of the team (five members) is required to act as the leader of a section of the project. There are five main leadership development sections: (1) responsibility for calling meetings and keeping minutes (transactional-transformational leadership), (2) coordinating the research (relational leadership), (3) coordinating the written report (information-processing leadership), (4) coordinating the preparation of the oral presentation (information-processing leadership) and (5) ensuring all students contribute to the group effort relating to the SER aspects of the project (connective leadership).

The teams hold five in-class meetings to review the technical progress of the project and determine actions for the following week. Each student takes a turn in leading a meeting, in line with his or her responsibility in the specific week. Students receive guidance from instructors on how to compile invitations to meetings, draft agendas and take minutes. Instructors introduce examples of bestpractise teamwork and leadership principles. Students are required to reflect on an online discussion board on their own and perform a peer evaluation of the various aspects of leadership developmental outcomes of each section of the project during in-class meetings over the six-week project. Minutes of meetings reflect the self- and peer reviews. The minutes of meetings form the basis of engagement marks for students. Weekly engagement marks flow from the quality of formally adopted minutes of meetings, with specific reference to the peer review components of leadership responsibilities (Watty et al., 2014). Students are required to submit a final, individual reflection on how they developed leadership attributes appropriate to their area of responsibility. Assessments were aligned with the leadership-in-team activities and intended learning outcomes through grading against a marking rubric (Biggs, 1996).

Students completed an evaluation survey that included a range of questions relating to the teamlearning experience. All students were invited to participate in interviews. Fifteen students responded to 
the request for interviews. The researchers compared the ethnicity, mode of study and age of the 15 respondents with the self-reported attributes in the student survey to ensure the attributes of the respondents in the sample were representative of the student cohort. Informal consultations were held with students from the larger student cohort. By following a snowballing and purposive approach ${ }^{2}$ (Neuman, 2013, pp. 269-276), 12 students were formally interviewed with the necessary ethical clearance. The researchers consider the resulting adaptive sample of approximately $10 \%$ to be representative of the demographic ethnicity of the student cohort. Based on the informal feedback received from informal consultations within the cohort, the researchers further consider the adaptive, judgemental or purposive sampling approach the most appropriate in this 'highly specific and difficult to reach population' (Neuman, 2011, p. 273) to derive views from the sample that are representative of age, teamwork experience and the two modes of studying available to students. Eight students identifying as female, and four students identifying as male were interviewed. The sample is broadly representative of the balance of females to males in the cohort. The interviewees were aged between 21 and 38 years old, which represented a range between youngest and oldest student in the cohort. The interviewee attributes, including ethnicity, together with workplace and educational experience, are reflected in Table 1 to provide context for interpretation of the responses to open-ended questions.

\section{<Insert Table 1>}

\subsection{Data collection and analysis}

Approximately 110 accounting students enrolled for the unit. Self-reported demographics indicate over $95 \%$ of students consider themselves to be international accounting students. To develop an

\footnotetext{
${ }^{2}$ The snowballing and purposive approach allows researchers to gain insights into research questions on the basis that sample sufficiency is reached when the respondents' answers are considered sufficiently similar to derive meaning (Neuman, 2013). In this study, 12 interviews were deemed sufficient, as common themes crystallised from analyses of the data.
} 
understanding of why MPA students do not take up leadership positions in academic teams, the researchers used adaptive sampling to ensure a comprehensive story evolved from the sample comprising a cross-section of students who are differently privileged in terms of teamwork experience, ethnicity and gender (Neuman, 2013, p. 274).

The questions posted to the interviewees were structured as open-ended to facilitate a thematic narrative analytical approach (Chase, 2005; Riessman, 2008). The open-ended questions were based on the three themes of the RWA framework and were posted as three different questions, namely: (1) Do you think, yourself included, all MPA students are ready to be leaders in academic teams? (2) Do you think, yourself included, all MPA students are willing to be leaders in academic teams? (3) Do you think, yourself included, all MPA students are able to be leaders in academic teams? To elicit opinions on why students may not be ready, willing, or able to take up such positions, students were asked to expand on their position when providing a negative answer. Responses from interviewees were considered collectively by following a snowball approach and thereby a deeper discussion during subsequent interviews. The researchers held informal discussions with other students to gain reassurance that the findings from the sample were consistent with views from the larger student cohort.

The raw narratives were recorded and transcribed by the researchers to reflect the interviewees' words verbatim. The researchers developed an improved understanding of the community of accounting students' narrative through multiple listening of the recordings, thus looking more closely at the stories that the accounting student community tells about itself (Lapan et al., 2011). The transcribed interviews were then analysed using a thematic narrative approach (Josselson, 2011; Riessman, 2008). Textual analytical software, NVivo, was used to code the textual data against the three RWA themes (Bazeley, 2007). 
Rather than placing undue importance on the frequency of words and other similar content analysis approaches (Krippendorff, 2004), the thematic narrative analysis aims to retain the character of the stories (McAdams, 2012). Narrative analysis approaches run the risk of becoming second-order restorying, with undue reliance being placed on responses from individual interviewees. The researchers acknowledge that respondents may story their experiences differently in different settings, for different audiences and when the reasons for telling may differ (Mishler, 2004). The researchers endeavoured to improve the validity of our findings by secondary reviewing of the coding protocols and co-analysis of data. During co-analysis, researchers were mindful not to place undue reliance on individual responses to derive meaning.

By making the methodical approach explicit, providing a synopsis of data and describing how interpretations were produced, the researchers aim to show the pragmatic validity of the data and interpretations by allowing other researchers to arrive at the same or different conclusions (Riessman, 2008). The discussion of our findings follows.

\section{Results and discussion of findings}

The age of the respondents varies from 21 to 38 years old. Pseudonyms are used throughout to protect anonymity. From the data (a synopsis provided in Table 1), the researchers observe interviewees felt they generally had extensive leadership-in-teams experience. However, three respondents did not consider themselves to have held leadership positions in a work environment (Terry, aged 21; Karen aged, 27; and Maureen, aged 28). The self-adoption of leadership roles in an accounting case-based project thus provides a valuable opportunity for less experienced students to strengthen their leadership skills (Huff, 2014). Many interviewees believed some of their team members showed poor leadership skills due to a lack of experience (Desire, Karen, Lisa, Maureen, Riana, Leon, Susan, and Fred). Most of these respondents highlighted that past workplace experience greatly improves a team 
member's leadership skills. Some respondents highlighted that improved communication skills go hand in hand with improved confidence and leadership skills (Desire and Sandra). It is also noted that adopting leadership roles can be quite challenging for some personality types (Karen, Cas, and Sandra), especially for those that Cas refers to as introverts.

For those students that have some work experience, the ability to direct, supervise and review, from a basis of superior technical competency, was a common theme. For example, Fred remarks,

.... you must be knowledgeable in the units because you don't have any other tools or power [to manage]. Your authority comes from your knowledge they don't have, or you have the skills they don't have....

The data suggest that the respondents mostly view leadership in line with notions of the transactionaltransformational school of leadership (Bass, 1997) by considering strong technical attributes an imperative for capacity to lead. It also appears as if accounting students' past work experience plays an important role in developing and reinforcing respondents' transactional-transformational views of leadership - more so than age or ethnicity. For example, Lisa explains that notions of the traditional command-and-control models of leadership, highly valued in business, serve as her point of reference:

When I am a group leader, I will assign the work, [explain] what one person should do and what another should do, and I will oversee what they work [have done] and then I will analyse how they worked. This is what I do [did] in my work experience.

The researchers consider it a real possibility that in underestimating the extent of our students' work experience, accounting educators are possibly attempting to teach traditional leadership skills some students already possess. In addition, while experience in authoritarian leadership models holds value in 'getting-the-job-done', students require exposure to a much broader repertoire of leadership skills to deal with demands of an increasingly connected but diverse global business environment characterised 
by contentious networks (Lipman-Blumen, 1992). The findings do suggest that at least some students will benefit from nuanced curricula to create alternative pathways for those students that are already effective transactional-transformational leaders (Collier and Rosch, 2016).

From the general overview of the students' leadership experience, it is apparent that a myriad of reasons influences individuals in deciding to take on academic leadership roles, hence the need for a schema or framework to analyse these interviewee responses. For example, self-serving bias was apparent through Cas's observation,

...what can you palm off to someone else...?

And Lisa remarking,

At the end of the day if I can get better marks by someone else taking leadership and doing the work, it is better for me than - I can spend time on other things - but you are not always that lucky.

Viewed in isolation, it is not immediately clear why Cas and Lisa avoid accepting leadership responsibilities. The underlying reasons for actively avoiding these situations require further exploration. Through detailed analysis against the constructs of the RWA framework below, a deeper more meaningful understanding of reasons why students avoid leadership positions was developed. Table 2 offers a synopsis of the main strengths and weaknesses observed from application of the RWA framework with a discussion of the three RWA dimensions following the table:

<Insert Table 2>

\subsection{The RWA framework - readiness to lead}

The respondents who offered an opinion largely agreed that MPA students should be ready to lead. For example, Desire remarks, 
This is a master course. If it was an undergrad course I would say yes, you have limited experience in teamwork, but no ... you should have a certain level of ability at master level to lead a team. How else did you get into the course?

Considered collectively with responses from the previous section, it appears that in addition to prior work experience, teamwork experience in academic settings can also be a proxy for strong leadership. Of interest to accounting educators is how best to improve higher-order leadership abilities of students if members in an academic team are already reasonably competent in transactional-transformational leadership (Lipman-Blumen, 1992). Leadership not only means allocating roles in a command-andcontrol manner (Bass, 1997), but also encompasses the attributes necessary to coordinate team activities (Graen and Uhl-Bien, 1995) and exploit team skills among the group (Lord et al., 1984).

Lisa was very hesitant in offering an opinion in suggesting that some students may simply not be ready to lead because 'somebody [may] only be good at being a kind of assistant'. Lisa's hesitance could be interpreted as a lack of confidence in the ability to lead. This was a common theme which flows from students' perceptions that fellow team members avoided leadership because they were not confident (Mark, Terry and Riana). Mark explains that having past work experience improves confidence in ones' readiness to lead:

I can understand that students that never worked outside, will have less confidence to lead someone else. They are not confident in their own opinions - especially to direct others.

Mark's response lends support to Rosch and Nelson's (2018) contention that individuals with a lack of experience in formal organisations are disadvantaged in developing leadership skills. Hesitance in accepting leadership should be distinguished from active avoidance. The researchers note some responses which suggest some students are not only hesitant in accepting leadership roles but even fearful (Maureen, Cas, Sandra, and Fred). Maureen suggests that a lack of technical competence and 
English communication skills is the main cause of the fear, while Sandra refers to peer pressure and Fred to the new, foreign environment as being contributing factors to anxiety, especially of young international female students.

There are suggestions that business simulation and work-integrated teamwork activities constructively aligned (Biggs, 1996) with learning outcomes designed around leadership theories may remedy this deficit to some extent (Lisa, Maureen, and Fred). Lisa and Fred, however, caution that business simulation in education is constrained by the lack of reward systems and punitive measures. What is of great interest from a teaching perspective is the potential of more experienced students to assist their less experienced peers to improve their leadership skills:

If you are not familiar with leadership, you can always communicate with a team member. Just do a little bit. Do your part and in the process, you will gain experience (Desire).

People can learn from the leaders you used to know. They remember it and somehow it integrates in your blood. So, I think somehow, they have the potential (Fred).

This would suggest that an opportunity exists for students experienced in transactional-transformation leadership models to mentor less experienced students with the guidance of competent facilitators (Rosch and Nelson, 2018).

The researchers argue that the readiness of disadvantaged students can be improved through business case teaching (Keevy, 2016) and work-integrated learning (Barac, 2009). By structuring teams with a balance of experienced (as mentors) and less experienced (as trainees), members of both categories of students will benefit (Van Der Laan Smith and Spindle, 2007). Based on the findings of Rosch (2015), developmental activities should be guided by pre-activity forethought and post-experience reflections.

\subsection{The RWA framework - willingness to lead}


The willingness dimension elicited the most responses from the interviewees. Self-serving bias, often because of normal life commitments, was offered as a reason why students are not willing to engage in leadership-in-teams developmental activities. Time constraints resulting from parental duties and work commitments were commonly reported. For example, an agitated Desire observed that students prioritise normal life commitments above study commitments:

They concentrate on other stuff, like their work or other priorities.... One member said she was too busy with work - I think she did have a job - and sometimes another one would say 'I have to take care of my baby.' (Desire).

Exposing international students to Australian social constructs will prepare students for economic and social life (Boyce et al., 2012). The willingness to lead in group structures to produce high-quality assignments is critical in showing evidence of the development of professional values (Bryant and Albring, 2006). Universities need to ensure that international students are on an equal footing with domestic students to participate in, and gain from, leadership exposure in teamwork (Cruickshank et al., 2012).

Social cognition plays a role in willingness to lead, with Cas, Sandra and Riana remarking that students are concerned about what their peers may think of them if they make mistakes:

If we get a low mark in this unit, I think the other 2 members will blame us-yeah, blame our team leader and I think that is because the team leader governed the whole thing (Sandra).

But if you want to guide someone, and you have not known them for a long time, what if they don't want to listen to you? What do you say? I think it is hard to gather them - some students. You are also just a student - you are the same level as me - I don't want to listen to you (Riana). 
Integration of international students on Australian campuses, as elsewhere, is critical for educational success and future career development. International students' lack of willingness to engage in teamwork activities and leadership opportunities detracts from their whole-of-campus experience. Embracing leadership development opportunities will lead to improved academic and social outcomes, which in turn will lead to career benefits and developing resilience in the face of challenging situations (Nguyen, 2016).

\subsection{The RWA framework - ability to lead}

Our analysis reveals that some Chinese students believe they are disadvantaged because the Chinese educational system does not adequately prepare them for the comprehensive teamwork approach to teaching and learning in Australian MPA programs:

\section{.... participation in teamwork is not a major part of the Chinese educational system, so they won't} have as much experience. They may be used to work individually and do not really understand how important teamwork is. From my perspective the Chinese educational system only focuses on getting the highest possible mark in the final exam (Mark).

Considering recent criticisms levied against Australian universities of treating international accounting and business students as cash cows (Nyland et al., 2013), policy makers and administrators should be mindful of the additional support some international students need in developing the necessary professional or soft skills required in a competitive business environment (De Villiers, 2010; Pham and Thompson, 2019).

As university representatives in the classroom, accounting educators have the responsibility to highlight system deficiencies and urge executive managers to direct resources to address these inequalities. In the context of this unit, the application of cost and management accounting techniques were complemented by the introduction of a leadership-in-teams learning outcome. The introduction of the 
new learning outcome and related activities and assessments is considered reasonably successful for high-achieving students. However, it became apparent that although students mostly developed the skills required to meet the technical learning outcomes, at least some students found it difficult to master the leadership-in-teams learning outcomes as a result of low levels of self-efficacy resulting from a lack of past teamwork experience and perceptions of poor English skills.

\subsection{A schema for the future}

The researchers postulate that hesitance in accepting leadership positions can be addressed through subtle prompts, support, rewards, and appropriate training. Accounting educators must endeavour to understand the developmental needs of individual students (Rosch, 2015), a challenging proposition where students do not disclose the reasons for not engaging in learning activities. The RWA model allows educators to guide students through an appropriate suite of models. By leveraging the RWA framework, the researchers through the student narrative explored in this study, offer the following schema to embed student leadership development in accounting education:

\section{$<$ Insert Figure 1>}

The RWA schema (Figure 1) shows that to improve our students' readiness to lead (left-hand column), educators should endeavour to enhance our students self-efficacy in their leadership capabilities. Selfefficacy in this context refers to the level of self-awareness about the individual's confidence in their own ability to act in a leadership capacity (Beatson et al., 2019). Students with low self-efficacy will benefit from remedial programs designed to improve their readiness to lead. For example, students with low levels of confidence in their English proficiency can be supported with short courses in grammar and language, social learning arrangements and reflective essay writing (Bonanno et al., 1998). Similarly, readings, self-evaluation programs and reflective journals will support the development of emotional intelligence in students to improve their readiness to lead (Daff et al., 2012). Students with a lack of 
leadership experience should initially be exposed to the transactional-transformational school of leadership (Bass, 1997). Through subtle prompts, aspirational qualities of great leaders should be benchmarked in a manner designed to increase students' readiness to take on leadership roles. Greater understanding on the impact of English as a second language on self-efficacy with leadership within accounting education is required.

The RWA schema in figure 1 shows that in order to enhance students' willingness to be leaders, learning outcomes should subsequently embed activities and assessment practices such as reflection on trust and mutual respect between leaders and followers - the relational school of leadership (Graen and UhlBien, 1995). From our findings, it is clear that the concerns our students hold about being competent leaders require learning outcomes to include exposure to leadership styles which focus on a leader meeting followers' expectations across a variety of cultural contexts - the information-processing school of leadership (Lord et al., 1984). Students with proven high levels of readiness resulting from leadershipin-workplace experience should act as mentors (relational leadership style). For those not willing due to work and/or family commitments, allocate leadership roles during in-class business simulated activities (Information processing leadership style).

To improve accounting students' ability to lead, educators should consider forming teams with a balance of experienced and inexperienced members in the various types of leadership skills. Learning objectives should be designed to develop the higher-order leadership skills of experienced students by introducing work-integrated initiatives. Work integrated learning in accounting education hold the added advantage of improving the work readiness of accounting graduates. Examples of such initiatives include workplace internships, credentialing, and co-operative degrees (O'Connell et al., 2015). O'Connell et al. 2015 advocates for more learning opportunities for accounting students to develop their professional skills, including their ability to lead. Opportunities should be created to practise leadership and other professional skills under the auspices of mentors - learning from practitioners, and fellow students' with 
proven ability to lead derived from past leadership experience in both the work and academic environment (O'Connell et al., 2015, Recommendation 14).

In response to the recommendations of O'Connell et al., (2015), O'Connell et al., (2016) and Watty et al. (2014) our schema in figure 1 shows how appropriate leadership outcomes can be developed by benchmarking external learning standards, in the case of Australia - AALS. As reflected upon earlier in the paper, through alignment of our learning outcomes and our activities and assessment practices with external accounting learning standards, we can provide evidence of meeting the demands of our stakeholders (Birrell \& Betts, 2018; O'Connell et al., 2015). We propose adoption of the RWA schema presented in this paper can act as a 'curriculum design tool' to assist educators to embed and scaffold leadership development into their courses (Daff et al., 2012; Dyball et al., 2007). Exposure to different schools of thoughts on leadership (For example - Bass, 1990; Graen and Uhl-Bien, 1995; Lord et al., 1984) with the opportunity to practise and reflect on each will benefit students in their future careers. By adopting the RWA schema we argue educators are in a better position to meet our stakeholders' demands for stronger leadership to 'make-the-world-a-better-place' (Lipman-Blumen, 1992).

\section{Conclusion}

The study sought to provide practical and theoretical insights for accounting educators who are expected to develop leadership qualities in cohorts of accounting students, including international students. Using the Keating et al. (2014) RWA framework, we respond to the call by Daff et al. (2012) for accounting educators to consider more rigorous adoption of emotional intelligence competencies by including more initiatives designed to develop accounting students' leadership abilities to inspire and develop others.

Employers have high expectations of advanced graduate learning outcomes being embedded in the accounting curriculum and practice-based activities and assessment. However, embedding these 


\begin{abstract}
learning outcomes in accounting curricula is complicated by large classes, ever-shortening teaching timeframes and a paucity of professional development for accounting educators at the 'coal face'. In response to the challenges highlighted by Birrell and Betts (2018), Daff et al. (2012), Dyball et al. (2007), and others, we provide an RWA schema to assist educators to inculcate a range of leadership styles as a professional skill development in a large international student cohort.
\end{abstract}

It appears intuitively likely that work experience, ethnicity, age, and gender influence leadership selfefficacy. Our main practical finding is that previous work experience does indeed play an important role in students' confidence in accepting leadership roles. Building on the calls of Keevy (2016) and Kennedy and Dull (2008), for more structured simulated business case studies to improve practical teamwork and leadership-in-teams skills, we suggest that educators in accounting programs should consider our students past work experience when structuring teams and developing leadership-in-teams competencies. Mentorships programs should be cultivated.

However, educators cannot solely rely on classroom activities to develop leadership competencies. If educators are to deliver on learning standards for graduates' professional skills, such as innovative and inspiring leadership, they need to purposefully scaffold these learning outcomes to encapsulate the various styles of leadership through an entire course of study. In order to facilitate the development of leadership development throughout the accounting curricula, we offer the RWA schema as guidance (Figure 1) for educators seeking to embed the scaffolding of professional skills development together with structured forethought and post-activity reflection through the stages of introduction through to mastery. Multiple study 'touchpoints' of professional skills development would ensure such skills receive the same value relevance as core discipline knowledge receives in accounting courses. Accounting course structures embedding scaffolded professional learning ought to be a foremost consideration during periodic, whole-of-course reviews which are required to be undertaken by regulators in different jurisdictions. 
We acknowledge that these findings are limited by self-selection and are likely biased towards the more experienced/extroverted students in our cohort. We hasten to add that this study suffers from a limited sampling frame, so the generalisability of results should be approached with caution. To address these limitations, and in light of the urgent need for strong and innovative leaders in political, business and accounting education, the researchers call for support of our findings by surveying and interviewing a broader cohort of accounting students, across a number of jurisdictions, in a more robust trial by applying the RWA schema presented in this study.

\section{Bibliography}

ABDC. (2017), 'Accounting learning standards', Australian Business Deans Council, available at: https://abdc.edu.au/data/Accounting LS/New TLS Final 2016.pdf (accessed 15 March 2017).

Bacon, D.R., Stewart, K.A. and Silver, W.S. (1999), 'Lessons from the best and worst student team experiences: How a teacher can make the difference', Journal of Management Education, Vol. 23 No. 5, pp. 467-488.

Barac, K. (2009), 'South African training officers' perceptions of the knowledge and skills requirements of entry-level trainee accountants', Meditari Accountancy Research, Vol. 17, No. 2, pp. 19-46.

Bass, B.M. (1990), 'Does the transactional-transformational leadership paradigm transcend organizational and national boundaries?', American Psychologists, Vol. 52 No. 2, pp. 130-139.

Bazeley, P. (2007), Qualitative data analysis with NVivo, Sage Publications Inc, London.

Beatson, N. J., Berg, D. A., and Smith, J. K. (2019), 'The Sheldon effect: fixed mindset does not always mean fragile confidence', Accounting Education, Vol. 28 No. 5, pp. 532-552. 
Biggs, J. (1996), 'Enhancing teaching through constructive alignment', Higher Education, Vol. 32 No. 3, pp. 347-364.

Birrell, B. and Betts, K. (2018). 'Australia's higher education overseas student industry: In a precarious state', The Australian Population Research Institute, Melbourne, Australia, available at: https://tapri.org.au/wp-content/uploads/2016/04/final-report-overseas-student-industryV2.pdf (accessed 30 May 2019).

Bonanno, H., Jones, J. and English, L. (1998), 'Improving group satisfaction: Making groups work in a first-year undergraduate course', Teaching in Higher Education, Vol. 3 No. 3, pp. 365-383.

Boyce, G., Greer, S., Blair, B. and Davids, C. (2012), 'Expanding the horizons of accounting education: Incorporating social and critical perspectives', Accounting Education, Vol. 21 No. 1, pp. 47-74.

Bryant, S.M. and Albring, S.M. (2006), 'Effective team building: Guidance for accounting educators', Issues in Accounting Education, Vol. 21 No. 3, pp. 241-265.

Cartwright, C.T. (2012), 'Assessing the relationship between intercultural competence and leadership styles: An empirical study of international fulbright students in the U.S', PhD thesis, Portland State University, DOI 10.15760/etd.759.

Chase, S.E. (2005), 'Narrative inquiry: Multiple lenses, approaches, voices', in NK Denzun and YS Lincoln (eds), The Sage Handbook of Qualitative Research, 3 edn, Sage Publications Inc, Thousand Oaks, CA, pp. 651-680.

Clegg, S. and Stevenson, J. (2013), 'The interview reconsidered: context, genre, reflexivity and interpretation in sociological approaches to interviews in higher education research', Higher Education Research and Development, Vol. 32 No. 1, pp. 5-16. 
Collier, D.A. and Rosch, D.M. (2016), 'Effects associated with leadership program participation in international students compared to domestic students', Journal of Leadership Education, Vol. 15 No. 4, p. 33.

Cruickshank, K., Chen, H. and Warren, S. (2012), 'Increasing international and domestic student interaction through group work: A case study from the humanities', Higher Education Research And Development, Vol. 31 No. 6, pp. 797-810.

Daff, L., De Lange, P. and Jackling, B. (2012), 'A comparison of generic skills and emotional intelligence in accounting education', Issues in Accounting Education, Vol. 27 No. 3, pp. 627-645.

De Villiers, R. (2010), 'The incorporation of soft skills into accounting curricula: preparing accounting graduates for their unpredictable futures', Meditari Accountancy Research, Vol. 18, No. 2, pp. 1-22.

Dyball, M.C., Reid, A., Ross, P. and Schoch, H. (2007), 'Evaluating assessed group-work in a second-year management accounting subject', Accounting Education, Vol. 16 No. 2, pp. 145-162.

Ellis, J.B., Riley, M.E. and Shortridge, R.T. (2015), 'Teaching and educational notes: Incorporating face-toface peer feedback in a group project setting', Journal of Accounting Education, Vol. 33, pp. 317-331.

Evans, E., Tindale, J., Cable, D. and Mead, S.H. (2009), 'Collaborative teaching in a linguistically and culturally diverse higher education setting: A case study of a postgraduate accounting program', Higher Education Research And Development, Vol. 28 No. 6, pp. 597-613.

Graen, G. and Uhl-Bien, M. (1995), 'Relationship-based approach to leadership: Development of leadermember exchange (LMX) theory of leadership over 25 years: Applying a multi-level multi-domain perspective', Leadership Quarterly, Vol. 6, pp. 219-247. 
Huff, P.L. (2014), 'The goal project: A group assignment to encourage creative thinking, leadership abilities and communication skills', Accounting Education, Vol. 23 No. 6, pp. 582-594.

Josselson, R. (2011), 'Narrative research: Constructing, deconstructing and reconstructing story', in Five ways of doing qualitative analysis: phenomenological psychology, grounded theory, discourse analysis, narrative research, and intuitive inquiry, Guilford Press, New York, NY.

Kaciuba, G. (2012), 'Teaching and educational note: An instructional assignment for student engagement in auditing class: Student movies and the AICPA core competency framework', Journal of Accounting Education, Vol. 30, pp. 248-266.

Keating, K., Rosch, D. and Burgoon, L. (2014), 'Developmental readiness for leadership: The differential effects of leadership courses on creating "ready, willing, and able" leaders', Journal of Leadership Education, Vol. 13 No. 3, pp. 1-16.

Keevy, M (2016), 'Using case studies to transfer soft skills (also known as pervasive skills): Empirical evidence', Meditari Accountancy Research, Vol. 24, No. 3, pp. 458-474.

Kennedy, F.A. and Dull, R.B. (2008), 'Transferable team skills for accounting students', Accounting Education, Vol. 17 No. 2, pp. 213-224.

Krippendorff, K. (2004), Content analysis: An introduction to its methodology, 2 edn, Sage Publications Incorporated, Thousand Oaks, CA.

Lapan, S.D., Quartaroli, M.T. and Riemer, F.J. (2011), Qualitative research, John Wiley \& Sons, Incorporated, Hoboken, NJ.

Lipman-Blumen, J. (1992), 'Connective leadership: Female leadership styles in the $21^{\text {st }}$ century workplace', Sociological Perspectives, Vol. 35 No. 1, pp. 183-203. 
Lord, R.G., Foti, R.J. and De Vader,C.L. (1984), 'A test of leadership categorization theory: Internal structure, information processing, and leadership perceptions' Organizational Behavior and Human Performance, Vol. 34 No. 3, pp. 343-378.

McAdams, D.P. (2012), 'Exploring psychological themes through life-narrative accounts', in J.A. Holstein and J.F. Gubrium (eds), Varieties of narrative analysis, Sage Publications Inc, Thousand Oaks, CA, pp. 1532.

Mishler, E.G. (2004), 'Historians of the self: Restorying lives, revising identities', Research in Human Development, Vol. 1 No. 1 and 2, pp. 101-121.

Nelson, M.W., Proell, C.A. and Randel, A.E. (2016), 'Team-oriented leadership and auditors' willingness to raise audit issues', Accounting Review, Vol. 91 No. 6, pp. 1781-1805.

Neuman, W.L. (2013), Social research methods : Pearson new international edition, Pearson Education Limited, available at: https://ebookcentral-proquest-com (accessed 15 June 2019).

Nguyen, D.H.K. (2016), 'Student success through leadership self-efficacy: A comparison of international and domestic students', Journal of International Students, Vol 6 No. 4, pp. 829-856.

Nyland, C., Forbes-Mewett, H. and HÄRtel, C.E.J. (2013), 'Governing the International Student Experience: Lessons from the Australian international education model', Academy of Management Learning \& Education, Vol. 12 No. 4, pp. 656-673.

O'Connell, B., Carnegie, G.D., Carter, A.J., De Lange, P., Hancock, P., Helliar, C.V. and Watty, K. (2015), Shaping the future of accounting in business education in Australia, CPA Australia, Melbourne, Australia. 
O'Connell, B., De Lange, P., Freeman, M., Hancock, P., Abraham, A., Howieson, B. and Watty, K. (2016),

'Does calibration reduce variability in the assessment of accounting learning outcomes?', Assessment \& Evaluation in Higher Education, Vol. 41 No. 3, pp. 331-349.

Pham, T., and Thompson, C. (2019), What do international students need to compete locally?, University World News, available at:

https://www.universityworldnews.com/post.php?story=20190617095020180ht (accessed 23 June 2019).

Reitsma, G.M., Fouché, J.P. and Viviers, H.A. (2016), 'Developing soft skills (also known as pervasive skills): Usefulness of an educational game', Meditari Accountancy Research, Vol. 24, No. 3, pp. 368-389.

Riessman, C.K. (2008), Narrative methods for the human sciences, Sage Publications Inc, Los Angeles, CA.

Robinson, N. (2018), 'Australia hosting unprecedented numbers of international students', available at: http://www.abc.net.au/news/2018-04-18/australia-hosting-unprecedented-numbers-internationalstudents/9669030 (accessed on 15 May 2018).

Rosch, D. (2015), 'Effects of Classroom-based Team Experiences on Undergraduate Student Leadership Development: When Practice Does Not Make Perfect', Journal of Leadership Education, Vol. 14, No. 3, pp. 104-118.

Rosch, D.M. and Nelson, N.E. (2018), 'The Differential Effects of High School and Collegiate Student Organization Involvement on Adolescent Leader Development', Journal of Leadership Education, Vol. 17, No. 4, pp. 1-16. 
Samkin, G and Stainbank, L. (2016), 'Teaching and learning: Current and future challenges facing accounting academics, academics, and the development of an agenda for future research', Meditari Accountancy Research, Vol. 24, No. 3, pp. 294-317.

Samuels, J.A. and Sawers, K.M. (2016), 'Arizona Microbrewery, Inc.: An Instructional Case on Management Decision Making', Issues in Accounting Education, Vol. 31, No. 4, pp. 409-415.

Stanley, T. and Marsden, S. (2012), 'Problem-based learning: Does accounting education need it?', Journal of Accounting Education, Vol. 30, No. 3-4, pp. 267-289.

Stainbank, L.J. (2009), 'Working in teams: improving the team experience', Meditari Accountancy Research, Vol. 17, No. 1, pp. 69-80.

Strand Norman, C., Rose, A.M. and Lehmann, C.M. (2004), 'Cooperative learning. resources from the business disciplines', Journal of Accounting Education, Vol. 22, pp. 1-28.

Van Der Laan Smith, J. and Spindle, R.M. (2007), 'The impact of group formation in a cooperative learning environment', Journal of Accounting Education, Vol. 25, pp. 153-167.

Watty, K., Freeman, M., Howieson, B., Hancock, P., O’Connell, B., De Lange, P. and Abraham, A. (2014), 'Social moderation, assessment and assuring standards for accounting graduates', Assessment \& Evaluation in Higher Education, Vol. 39 No. 4, pp. 461-478. 
Table 1: Respondents' attributes and data on experience

\begin{tabular}{|c|c|c|}
\hline Attributes & Leadership-in-teams workplace experience (identifiers removed) & Leadership-in-teams educational experience (identifiers removed) \\
\hline $\begin{array}{l}\text { Desire, Female, Age } 23 \\
\text { Chinese (Hong Kong) }\end{array}$ & $\begin{array}{l}\text { I am an employee in sushi shop....... [I think] teamwork is even more } \\
\text { important in small companies. I have just been promoted to supervisor in } \\
\text { the workplace. }\end{array}$ & $\begin{array}{l}\text { In units, I prefer if someone else takes the leadership role. If no one else wants to do } \\
\text { it, I will have to do it.... [I have had approximately] } 15 \text { teamwork experiences in } \\
\text { different units at XX and XX. }\end{array}$ \\
\hline $\begin{array}{l}\text { Karen, Female, Age } 27 \\
\text { Vietnamese }\end{array}$ & $\begin{array}{l}\text { I have experience in teamwork as an intern in business. I currently do part } \\
\text { time work in a sushi shop. I've not had any leadership experience in the } \\
\text { workplace. }\end{array}$ & $\begin{array}{l}\text { Almost all the units I have done [at XX] had a teamwork component. I did my } \\
\text { undergrad units in France. I would say between } 15 \text { and } 20 \text { units [over both courses] } \\
\text { had teamwork. }\end{array}$ \\
\hline $\begin{array}{l}\text { Terry, Female, Age } 21 \\
\text { Bangladesh }\end{array}$ & $\begin{array}{l}\text { I worked at the stock exchange in Bangladesh - as intern during my under- } \\
\text { graduate studies. After undergrad, I was also an intern at Slumberland. I was } \\
\text { still very young then - very young. I have no leadership experience in the } \\
\text { workplace. }\end{array}$ & $\begin{array}{l}\text { [I have done approximately] } 10 \text { units with teamwork. [I] will take leadership when } \\
\text { there is nobody better. For example, this tax module - he did the job amazingly. I was } \\
\text { extremely happy with what he did. }\end{array}$ \\
\hline $\begin{array}{l}\text { Mark, Male, Age } 32 \\
\text { Chinese (Mainland) }\end{array}$ & $\begin{array}{l}\text { [I have] quite a lot of experience in the workplace. [I] worked [for] } 9 \text { years in } \\
\text { China, of which at least } 6 \text { years at Deloitte - China. I led a small team of } 4 \text { to } \\
5 \text { full time people. }\end{array}$ & $\begin{array}{l}\text { [I have done teamwork in] } 5 \text { postgraduate [units] at XX and a little bit in China - } \\
\text { perhaps another } 5 \text { maximum at undergraduate in China. Not more than } 10 \text { units.... I } \\
\text { think I adopted leadership roles in my group assignments at XX. }\end{array}$ \\
\hline $\begin{array}{l}\text { Lisa, Female, Age } 33 \\
\text { Chinese (Mainland) }\end{array}$ & $\begin{array}{l}\text { I have experience in teamwork in the work environment. I am [was] an } \\
\text { internal auditor. I am [was] a small team leader in that group - 3M [in] } \\
\text { China. }\end{array}$ & $\begin{array}{l}\text { [I have had] no teamwork in China during my undergraduate studies - very little. At XX } \\
\text { I have had teamwork experience in roughly } 8 \text { units.... you are the group leader, no. } \\
\text { We separate the responsibilities for the work and after finishing our part we will } \\
\text { organise it together. }\end{array}$ \\
\hline $\begin{array}{l}\text { Maureen, Female, Age } \\
28 \\
\text { Chinese (Mainland) }\end{array}$ & $\begin{array}{l}\text { I have } 2 \text { years' working experience at Deloitte. I did not play any leadership } \\
\text { role at Deloitte. I was only there for } 2 \text { years. I was only an associate. }\end{array}$ & $\begin{array}{l}\text { [I have done] my undergraduate studies in China - little experience in China in } \\
\text { teamwork. At XX most units have teamwork. I have very little experience in leadership } \\
\text { in teamwork at University. Being an international student, my English is not so good. } \\
\text { Normally students with good English take [on] leadership roles. }\end{array}$ \\
\hline $\begin{array}{l}\text { Riana, Female, Age } 32 \\
\text { China (Shanghai) }\end{array}$ & $\begin{array}{l}\text { I have teamwork experience in Honeyware, Shanghai - a large American } \\
\text { company. It is a very big company. About 3,000 people work for the } \\
\text { company in that area. I was working in the financial department - the } \\
\text { disbursement team. I was the team leader with } 8 \text { people working with me. }\end{array}$ & $\begin{array}{l}\text { [In my] undergraduate studies in China - no teamwork. I have done } 10 \text { units at XX, } \\
\text { most of which has a teamwork component.... No, I did not take any leadership } \\
\text { responsibility because I don't want [to]. I will let the other students do the leadership, } \\
\text { because I was the leader [in the workplace]. }\end{array}$ \\
\hline Cas, Male, Age 30 & $\begin{array}{l}\text { About } 10 \text { years' experience in the commercial, retail and business } \\
\text { environment ...... I did a leadership program through a previous employer, }\end{array}$ & $\begin{array}{l}\text { I did my undergraduate studies at XX.... Within all the subjects I have done, there was } \\
\text { maybe } 6 \text { to } 7 \text { that required group work. I have another } 6 \text { that are left that may }\end{array}$ \\
\hline
\end{tabular}




\begin{tabular}{|c|c|c|}
\hline Australian (Distance) & $\begin{array}{l}\text { six or seven sessions with some outside consultant......I think it may have } \\
\text { helped somewhat in my teamwork in study units in giving me confidence to } \\
\text { know that I can get in and do stuff. }\end{array}$ & $\begin{array}{l}\text { require some more group work. In probably half of my units I took a leadership role. } \\
\text { In the latest one, I didn't, until basically right towards the end. }\end{array}$ \\
\hline $\begin{array}{l}\text { Leon, Male, Age } 30 \\
\text { Australian }\end{array}$ & $\begin{array}{l}\text { I would say I have been involved in teamwork for about } 8 \text { - } 9 \text { years in } \\
\text { working environments -pretty much all the time - but not any project type } \\
\text { work. I was also involved in small teams in infrastructure, sort of small 2- } \\
\text { person teams where I received instructions and had to report back.... I have } \\
\text { not really had any formal training in teamwork, but I have had some group } \\
\text { events where we did team building exercises. }\end{array}$ & $\begin{array}{l}\text { It was ages ago when I did Bachelors in IT. There was only } 2 \text {-3 units where we did } \\
\text { teamwork. We did one major teamwork project at the end, but mostly it was } \\
\text { individual assignments. In the MPA it is different. Pretty much every unit involves } \\
\text { some form of teamwork. Some are a bit heavy on it. On average, I would say } 50 \% \text { of } \\
\text { our assessment carry some element of teamwork. I would say, without sounding } \\
\text { arrogant, I carried leadership roles in most of the units where we did teamwork. }\end{array}$ \\
\hline $\begin{array}{l}\text { Sandra, Female, Age } 25 \\
\text { China (Mainland) }\end{array}$ & $\begin{array}{l}\text { I did an internship at a bank in China. I also worked at an employment } \\
\text { agency. I also had a part time job at McDonald's where there was a lot of } \\
\text { teamwork. The teamwork training at McDonald's was very formal.... You } \\
\text { have to communicate with your crew members. I was also trained in having } \\
\text { to do teamwork when we were busy - where you have conflict with your } \\
\text { customers. I also trained some crew members - like new crew members. }\end{array}$ & $\begin{array}{l}\text { I did my bachelor's degree in China. We did not have any teamwork [laughing]. I then } \\
\text { went to Melbourne. I did some language studies when I was there. We did do some } \\
\text { group work. I have done } 7 \text { perhaps } 8 \text { units where we did group work or teamwork. }\end{array}$ \\
\hline $\begin{array}{l}\text { Susan, Female, Age } 25 \\
\text { China (Mainland) }\end{array}$ & $\begin{array}{l}\text { I worked for a year when I was in China. I was working for an education } \\
\text { company. Our teamwork was very formal. I think the way we learned } \\
\text { teamwork was from the working process itself...I would say I did carry } \\
\text { leadership responsibilities in my work environment. }\end{array}$ & $\begin{array}{l}\text { I did my undergraduate studies in Sydney. We did some teamwork in my bachelor's } \\
\text { degree. So sometimes we needed to do group assignments. In econometrics } \\
\text { especially, we needed to work together on a group project. It is hard to tell in how } \\
\text { many units we did group work, I think every semester at least once. I would say } \\
\text { probably } 12 \text { in total. }\end{array}$ \\
\hline $\begin{array}{l}\text { Fred, Male, Age } 38 \\
\text { China (Mainland) }\end{array}$ & $\begin{array}{l}\text { I used to work in a team with } 100 \text { people and a car dealership in China. That } \\
\text { was the beginning of my leadership development. Then I worked for } \\
\text { Mercedes Benz - China. Basically the 3rd sector I worked in is about } \\
\text { Volkswagen. I did have some formal training in teamwork and leadership. In } \\
\text { Mercedes.... I had modular training which will give you leadership } \\
\text { excellence.... For Volkswagen I had even more strict training programs. We } \\
\text { had a globally recognised leadership program. }\end{array}$ & $\begin{array}{l}\text { I did a master program back in China. I would say for my Bachelor in China, I did not } \\
\text { do much teamwork. This is my 4th MPA unit that I am doing. I have done teamwork in } \\
\text { all the units in MPA.... Basically, yes, I would say I took leadership roles in most of the } \\
\text { MPA teamwork activities because basically I am very old [laughing] and people } \\
\text { basically assume that I have more experience. So, that is why they have trust, and } \\
\text { would like me to take the lead. I would also say it is a process of learning, an } \\
\text { opportunity to strengthen my leadership knowledge }\end{array}$ \\
\hline
\end{tabular}


Table 2: Synopsis of RWA strengths and weaknesses observed from interview transcripts

\begin{tabular}{|c|c|c|}
\hline & Strengths observed & Weaknesses observed \\
\hline $\begin{array}{l}\text { Readiness to lead } \\
\text { Students show confidence in their ability to lead }\end{array}$ & $\begin{array}{l}\text { - Students with past work experience display greater self-efficacy } \\
\text { in leadership (Most respondents) } \\
\text { - Improving English communication skills enhance confidence in } \\
\text { own leadership skills (Desire and Sandra) }\end{array}$ & $\begin{array}{l}\text { - Students avoid leadership roles because they are not confident } \\
\text { in their ability to lead (Mark, Terry and Riana) } \\
\text { - Some personality types, for example introverts, find leadership } \\
\text { roles very challenging (Karen, Cas and Sandra) } \\
\text { - Perceived lack of technical competency prevents students from } \\
\text { taking on leadership roles (Maureen) } \\
\text { - a new foreign environment leads to anxiety and results in } \\
\text { avoidance of leadership roles for young, international students } \\
\text { (Fred) }\end{array}$ \\
\hline $\begin{array}{l}\text { Willingness to lead } \\
\text { Students exhibit motivation to lead }\end{array}$ & $\begin{array}{l}\text { - Students with past work experience are mostly comfortable with } \\
\text { command-and-control models of leadership (Lisa) } \\
\text { - Past leadership experience in the workplace supported by formal } \\
\text { training is a strong motivation for students to accept mentoring } \\
\text { roles (Fred) }\end{array}$ & $\begin{array}{l}\text { - Self-serving bias, for example work and family commitments, } \\
\text { prevent students from taking on leadership roles (Desire, Cas } \\
\text { and Lisa) } \\
\text { - Peer pressure and fear of being blamed for poor results detract } \\
\text { from motivation to lead (Riana and Sandra) }\end{array}$ \\
\hline $\begin{array}{l}\text { Ability to lead } \\
\text { Expend energy to display the repeat of leadership skills }\end{array}$ & $\begin{array}{l}\text { - Experience from teamwork in academic settings enables } \\
\text { students primarily in transactional-transformational leadership } \\
\text { styles (Desire) } \\
\text { - Business simulation and work-integrated learning hold potential } \\
\text { to improve higher-order leadership development (Lisa, Maureen } \\
\text { and Fred) }\end{array}$ & $\begin{array}{l}\text { - The Chinese schooling system focusses on individualism in } \\
\text { achieving high marks with a perceived lack of opportunity to } \\
\text { practise leadership skills (Mark) }\end{array}$ \\
\hline
\end{tabular}


Figure 1: RWA schema for embedding leadership development in accounting curricula

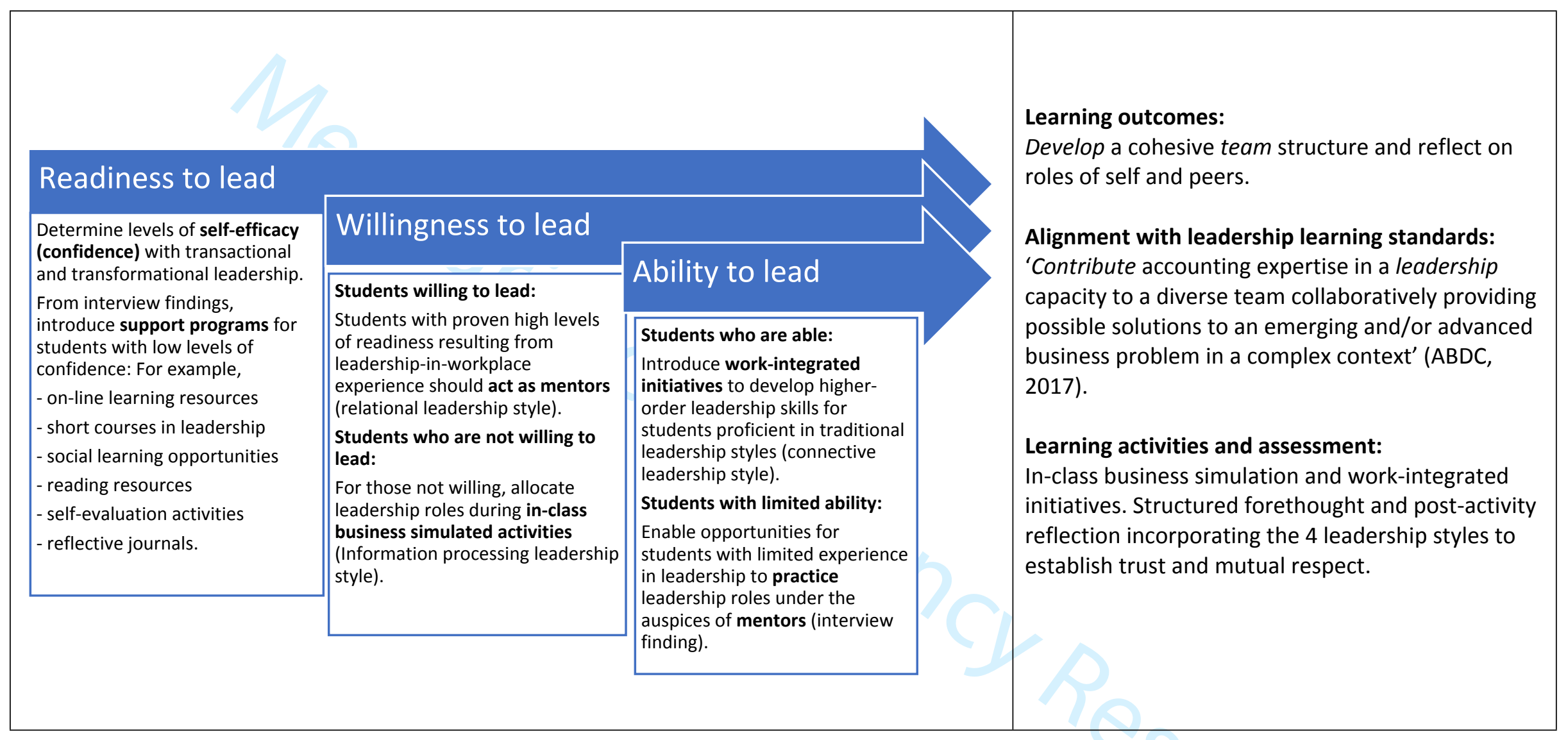

